\title{
DETERMINANTS OF DEPOSIT INSURANCE COVERAGE
}

\section{Yiming Chang, Shangmei Zhao, Haijun Yang, Jiang He, Fei Hu*}

\begin{abstract}
On a comprehensive duration data set covering 189 countries from 1960 to 2015, we employ a Heckman two-step selection model to investigate determinants of deposit insurance coverage. We find that macroeconomic status, bank structure and regulatory, political institution, legal system and deposit insurance design characteristics have a significant effect on deposit insurance coverage. Moreover, empirical results show that the impact factors are different between developing and developed countries, especially the design characteristics. Specifically, for developing countries, the scheme with the Foreign currency will support a higher coverage. And for developed countries, the Interbank deposits will lead to a lower coverage, but the No coinsurance shows the opposite effect. It is noteworthy that both the Payouts and Backstop from government influence the coverage setting conversely in different samples, which implies that there may be higher banks' risk-taking incentives in developing countries after setting up explicit deposit insurance system.
\end{abstract}

Keywords: deposit insurance coverage, political economics, private interest theory, public interest theory, Heckman two-step model

JEL Classification: G21, G22

\section{Introduction}

The deposit insurance system has a significant role in keeping and promoting financial stability (Diamond and Dybvig, 1983). However, it also leads to adverse effects because the system can lessen the shareholders' responsibility and the depositors' enthusiasm of supervision so it weakens the market restrictions and increases banks' risk-taking, which will reduce the efficiency of deposit insurance system (Barth et al., 2004). As an important part of the deposit insurance scheme, coverage setting not only has a different impact on

* Yiming Chang, School of Economics and Management, Beihang University, Beijing, China (changyiming@buaa.edu.cn);

Shangmei Zhao, School of Economics and Management, Beihang University, Beijing, China; Institute of Economics and Business, Beihang University, Beijing, China (beihangzsm@163.com); Haijun Yang, School of Economics and Management, Beihang University, Beijing, China; Beijing Advanced Innovation Center for Big Data and Brain Computing, Beihang University, Beijing, China; Institute of Economics and Business and Management, Beihang University, Beijing, China (navy@buaa.edu.cn) - corresponding author;

Jiang He, School of Economics and Management, Beihang University, Beijing, China (hejiang686@163.com);

Fei Hu, School of Economics and Management, Beihang University, Beijing, China (hufeijr@sina.com). The authors appreciate the support provided by the National Natural Science Foundation of China under Grant No. 71771006 and 71373017. 
interest-concerned groups, but also contributes to raising public confidence and preventing bank failures (Angkinand and Wihlborg, 2010). Thus, coverage research has the great significance.

The purpose of this paper is to analyse the determinants of deposit insurance coverage by considering the deposit insurance design features and more comprehensive economic institution factors.

First, we specifically focus on whether the deposit insurance design features will improve (or impede) the coverage. Some design features directly or indirectly determine the effective coverage, such as Payouts, Unlimited government guarantees, Foreign currency and Interbank deposits, while the others also have a substantial impact on the coverage limit. Therefore, considering both the design features and economic institution together, this paper attempts to get a more reasonable conclusion and has a great significance to study the optimal coverage setting in the future. Second, after establishing the explicit deposit insurance system, multiple causes under the interaction of the various interest groups determine the design features of the scheme (Demirgüç-Kunt et al., 2008). Therefore, the observed values of the dependent variable Coverage ratio are not from the randomselection samples, which would lead to biased coefficient estimates (Greene, 1981; Heckman, 1976; Heckman, 1979). Thus we employ the Heckman two-step model in this paper to solve the problem of sample selection bias (Heckman, 1979). Third, to study the difference of the coverage determinants in various economic development levels and obtain robust conclusions (Angkinand and Wihlborg, 2010), we consider developing countries, developed countries and all countries as the empirical sample, respectively. Comparing the regression results from different samples, we find that the effects of Ex-ante fund and Non-deposit liabilities show consistency on the coverage setting, respectively. However, estimates of Payouts and Backstop from government show a distinct difference.

The rest of this paper is as follows: Section 2 summarizes the literature on the determinants of deposit insurance coverage. Section 3 discusses our data sources, defines and provides the summary statistics for the variables. Section 4 gives the specification of Heckman two-step model. Section 5 provides an empirical analysis of coverage determinants. Section 6 concludes the paper with a discussion.

\section{Theoretical and Literature Review}

The analytical framework of this article is based on the public interest and private interest theory of political economics. The public interest theory refers to the notion that the primary purpose of regulatory intervention is to protect the interests of the public (Diamond and Dybvig, 1983; Jayaratne and Strahan, 1996). The private interest theory treats the regulative process as a result of the continual competition from different interest groups. Since larger groups can, during this process, exert greater influence on politicians and regulators, regulatory intervention can make them occupy the dominant position when competing with those more dispersed groups (Becker, 1976; Becker, 1983; Jayaratne and Strahan, 1996; Kroszner and Stratmann, 1998; Stigler, 1971). The two theories are applied to the deposit insurance: Public interest of deposit insurance and private 
interest theory. The first one refers to protecting uninformed depositors and improving the stability of banking, so regulators prefer to restrain coverage set too high. Private interest theory indicates that deposit insurance scheme is favoured by higher risk-taking banks, because they could get the subsidy from the lower-risk banks under the system, so they have incentives to lobby regulators to set higher coverage to reduce the cost of their risk-taking. Apparently, two theories reflect the important aspects of the political decision-making process, respectively, but they are not mutually exclusive because any political result can be reasonably explained by the two theories (Laeven, 2004).

The literature pertaining to the deposit insurance coverage determinants is relatively little. As political economics approach aids an understanding of deposit insurance system design, Laeven (2004) and Demirgüç-Kunt et al. (2008) study the influence of external political and economic factors on the design by public interest and private interest theories of political economics. Laeven (2004) finds that the coverage setting is higher in countries where financial industry is less developed and people's education level is lower. However, he only uses a single equation method to explain the coverage setting. Demirgüç-Kunt et al. (2008) find moral hazard and coverage are higher in the countries with more government-owned banks, lower GDP per capita and weaker restrictions on regulators. International Association of Deposit Insurance proposed a governance of establishing deposit insurance system in 2009 and pointed out to the factors that should be taken into account, but this manual does not explain how these factors affect coverage setting (IADI, 2009). Recently, Shy et al. (2016) investigate the limited deposit insurance coverage, which is closely associated with the deposit insurance design feature Payouts, and find that limited deposit insurance weakens competition among banks and reduces total welfare relative to no or unlimited deposit insurance.

However, previous scholars do not account for design characteristics of the system that affect coverage setting (Demirgüç-Kunt et al., 2014). Further, their research tends to neglect the factors particularly critical for developing countries, such as intensive banking competition (Boyd and De NicolÓ, 2005), higher household savings rates (Aiyagari, 1994), bigger interest rate spread (Saunders and Schumacher, 2000) and lower bank-capital assets ratio and weak banking management (Acharya, 1996). Therefore, using an augmented dataset merged from several sources, this paper contributes to the literature by considering both deposit insurance design characteristics and more economic institution factors to research the determinants of coverage.

\section{Variable Definitions and Data Sources}

This section presents the definitions of variables, which influence the coverage based on the public and private interest theory of deposit insurance (Diamond and Dybvig, 1983; Jayaratne and Strahan, 1996). And all variables are Duration Data covering 189 countries during 1960-2015.

We consider the following macroeconomic variables: GDP per capita (in constant 2005 U.S. dollar) and GDP growth (in \%) are from the World Development Indicators Dataset (hereafter WDI), of which higher values reflect the faster development level in a country. Official exchange rate refers to local currency units relative to the U.S. dollar 
(in constant 2005); Interest rate spread (in \%), the greater value reflects the banks' income is more reliant on lending business; Fiscal surplus represents the ratio of budget surplus to GDP (in \%); Insurance penetration indicates gross insurance premiums underwritten as a share of GDP. These variables are from the WDI, and we use the mean value for 1960-2015. Household savings rate is defined as the subtraction of household consumption expenditure from household disposable income, divided by the disposable income. Data is from the EIU Countrydata of BVD and partial estimated values are from the WDI, we also use the mean value for 1960-2015. Bank crisis is a dummy variable from the Global Financial Development Database (hereafter GFDD). To reflect older voters' influence to national political decision-making, we use the indicator of Pop65. It represents the share of the population age 65 and over in a country, and data is from the WDI.

To reflect a domestic institutional environment, we consider the following variables: Political score refers to a national policy system status, data is from the Polity IV database from the University of Maryland; Bureaucracy refers to forces and quality of the bureaucratic institution system; Corruption refers to the assessment of the political system; Law and Order reflect the legal environment. These three variables are from the International Country Risk Guide. We use the mean value for 1960-2015.

To reflect the banks' structure and business, we consider the following four variables: Boone indicator which measures banking competition; A bank-capital assets ratio (hereafter Capta) is the ratio of bank capital and reserves to total assets, which measures whether a bank has sufficient capital to support its assets. These two variables are from the GFDD, and we average data for these two variables over 1960-2015. Small banks refer to the share of banks in the country with total assets less than US\$ 1 billion; Undercapitalized banks represent the proportion of banks in the country with capital-to-asset ratio less than the median capital-to-asset ratio in the country. Data of above two variables are from the Bankscope, we use the mean value over 1960-2015.

To reflect the bank regulatory level, we use four indexes by Barth et al. (2013): Capital regulatory index indicates stringency of bank management; Activity restrictions refers to the degree to which banks can engage in non-bank services; Entry restrictions is an index that measures regulatory requirements to obtain a license to set up a bank; Official supervisory power reflects the extent to which regulators have the authority to discipline banks by taking specific actions to prevent and correct problems. For the above four variables, higher values denote greater stringency, we use the mean value of each index (Barth et al., 2013).

We consider the following variables to measure pressure, force, and influence of establishing and developing deposit insurance systems around the world. Contagion represents a proportion of countries in the sample that has adopted explicit deposit insurance at each point in time; IMF represents the guiding role of establishing explicit deposit insurance for developing countries, which is a 0-1 indicator and takes one from 1999 on (Garcia, 2000); WB loan represents the indicator that takes one for countries beginning in the year the World Bank starts an adjustment lending programme that entailed employment of the system, and zero otherwise. Data is from the World Bank (2004). 
Table 1 | Summary Statistics

\begin{tabular}{|c|c|c|c|c|c|c|}
\hline Variable name & Mean & Median & Std. dev. & Minimum & Maximum & Number \\
\hline Explicit & 0.22 & 0.00 & 0.41 & 0.00 & 1.00 & 10,584 \\
\hline Coverage ratio (\%) & 4,408 & 5,360 & 2,197 & 3.34 & 48,914 & 10,584 \\
\hline Unlimited government guarantees & 0.00 & 0.00 & 0.07 & 0.00 & 1.00 & 10,576 \\
\hline Foreign currency & 0.15 & 0.00 & 0.35 & 0.00 & 1.00 & 10,576 \\
\hline Interbank deposits & 0.06 & 0.00 & 0.25 & 0.00 & 1.00 & 10,576 \\
\hline No coinsurance & 0.19 & 0.00 & 0.39 & 0.00 & 1.00 & 10,576 \\
\hline Payouts & 0.16 & 0.00 & 0.43 & 0.00 & 3.00 & 10,584 \\
\hline Premiums & 0.16 & 0.00 & 0.37 & 0.00 & 1.00 & 10,576 \\
\hline Ex-ante fund & 0.19 & 0.00 & 0.39 & 0.00 & 1.00 & 10,576 \\
\hline Funded by government & 0.00 & 0.00 & 0.06 & 0.00 & 1.00 & 10,576 \\
\hline Backstop from government & 0.08 & 0.00 & 0.28 & 0.00 & 1.00 & 10,576 \\
\hline Uninsured deposits & 0.21 & 0.00 & 0.41 & 0.00 & 1.00 & 10,576 \\
\hline Bank deposits & 0.03 & 0.00 & 0.17 & 0.00 & 1.00 & 10,576 \\
\hline Non-deposit liabilities & 0.05 & 0.00 & 0.23 & 0.00 & 1.00 & 10,576 \\
\hline Bank assets & 0.02 & 0.00 & 0.16 & 0.00 & 1.00 & 10,576 \\
\hline Administration & 0.36 & 0.00 & 0.78 & 0.00 & 3.00 & 10,576 \\
\hline Membership & 0.20 & 0.00 & 0.38 & 0.00 & 1.00 & 10,535 \\
\hline Boone indicator & -0.05 & -0.05 & 0.10 & -0.50 & 0.470 & 9,296 \\
\hline Bank-capital assets ratio & 9.74 & 9.55 & 3.68 & 3.03 & 20.77 & 6,888 \\
\hline Interest rate spread & 12.32 & 6.62 & 39.32 & -0.10 & 508.2 & 10,136 \\
\hline Small banks & 0.32 & 0.14 & 0.37 & 0.00 & 1.00 & 9,912 \\
\hline Undercapitalized banks & 0.70 & 0.70 & 0.63 & 0.00 & 8.070 & 8,792 \\
\hline Pop65 & 6.08 & 4.15 & 4.19 & 0.700 & 25.71 & 9,816 \\
\hline Bank crisis & 0.05 & 0.00 & 0.22 & 0.00 & 1.00 & 10,528 \\
\hline Polity score & 1.10 & 2.00 & 7.37 & -10.00 & 10.00 & 7,616 \\
\hline Log of GDP per capita & 7.23 & 7.11 & 2.14 & -9.57 & 20.26 & 10,472 \\
\hline GDP growth & 3.95 & 3.97 & 6.92 & -64.05 & 189.8 & 7,855 \\
\hline Inflation & 36.34 & 5.92 & 455.80 & -64.72 & 26766 & 7,838 \\
\hline Official exchange rate & 740,000 & 7.90 & $1.0 \mathrm{e}+07$ & 0.31 & $1.4 \mathrm{e}+08$ & 10,416 \\
\hline Household saving rate & 14.18 & 11.43 & 18.24 & -77.54 & 71.21 & 10,024 \\
\hline Fiscal surplus & -0.22 & -2.08 & 31.43 & -44.53 & 419.4 & 10,360 \\
\hline Insurance penetration & 2.42 & 1.46 & 2.40 & 0.05 & 12.26 & 9,128 \\
\hline Activity restrictions & 7.56 & 7.50 & 1.61 & 3.00 & 12.00 & 9,072 \\
\hline Entry restrictions & 7.66 & 8.00 & 0.59 & 4.75 & 8.00 & 9,128 \\
\hline Capital regulatory index & 6.61 & 6.75 & 1.63 & 1.00 & 10.00 & 7,784 \\
\hline Official supervisory power & 10.88 & 11.00 & 2.14 & 5.33 & 14.50 & 8,512 \\
\hline Bureaucracy & 2.09 & 2.00 & 0.95 & 0.00 & 4.00 & 9,744 \\
\hline Corruption & 2.98 & 2.78 & 1.05 & 0.64 & 5.99 & 9,688 \\
\hline Law and Order & 3.52 & 3.44 & 1.17 & 0.99 & 6.00 & 9,688 \\
\hline IMF & 0.30 & 0.00 & 0.46 & 0.00 & 1.00 & 10,584 \\
\hline WB loan & 0.02 & 0.00 & 0.15 & 0.00 & 1.00 & 10,584 \\
\hline EU candidacy & 0.03 & 0.00 & 0.16 & 0.00 & 1.00 & 10,584 \\
\hline Contagion & 0.22 & 0.14 & 0.19 & 0.01 & 0.57 & 10,584 \\
\hline
\end{tabular}

Note: Refer to Section 3.

Source: Authors. 
Table 2 | Correlation Coefficients of Deposit Insurance and Other Variables

\begin{tabular}{|c|c|c|c|}
\hline Variable name & Coverage ratio & Variable name & Coverage ratio \\
\hline Explicit & $-0.78^{* * *}$ & Pop65 & $-0.43^{* * *}$ \\
\hline Unlimited government guarantees & $-0.05^{* * *}$ & Bank crisis & $-0.16^{* * *}$ \\
\hline Foreign currency & $-0.56^{* * *}$ & Polity score & $-0.33^{* * *}$ \\
\hline Interbank deposits & $-0.32^{* * *}$ & Log of GDP per capita & $-0.30^{* * *}$ \\
\hline No coinsurance & $-0.69 * * *$ & GDP growth & $0.03^{* *}$ \\
\hline Payouts & $-0.56^{* * *}$ & Inflation & $0.03^{* * *}$ \\
\hline Premiums & $-0.70^{* * *}$ & Official exchange rate & -0.01 \\
\hline Ex-ante fund & $-0.68^{* * *}$ & Household saving rate & $0.02^{* *}$ \\
\hline Funded by government & $-0.11^{* * *}$ & Fiscal surplus & $0.03^{* * *}$ \\
\hline Backstop from government & $-0.45^{* * *}$ & Insurance penetration & $-0.17^{* * *}$ \\
\hline Uninsured deposits & $-0.77^{* * *}$ & Activity restrictions & $0.18^{* * *}$ \\
\hline Bank deposits & $-0.17^{* * *}$ & Entry restrictions & $0.12^{* * *}$ \\
\hline Non-deposit liabilities & $-0.42 * * *$ & Capital regulatory index & $-0.02^{*}$ \\
\hline Bank assets & $-0.31^{* * *}$ & Official supervisory power & $-0.03^{* * *}$ \\
\hline Administration & $-0.72^{* * *}$ & Bureaucracy & $-0.23^{* * *}$ \\
\hline Membership & $-0.80^{* * *}$ & Corruption & $-0.15^{* * *}$ \\
\hline Boone indicator & 0.008 & Law and Order & $-0.21^{* * *}$ \\
\hline Bank-capital assets ratio & $0.14^{* * *}$ & IMF & $-0.37^{* * *}$ \\
\hline Interest rate spread & -0.002 & WB loan & $-0.20 * * *$ \\
\hline Small banks & $0.25^{* * *}$ & EU candidate & $-0.24 * * *$ \\
\hline Undercapitalized banks & 0.005 & Contagion & $-0.40^{* * *}$ \\
\hline
\end{tabular}

Note: Refer to Section $3 .{ }^{*},{ }^{* *},{ }^{* * *}$ indicate the significance levels of $10 \%, 5 \%$ and $1 \%$, respectively. Source: Authors.

Motivated by the work of Demirgüç-Kunt et al. (2008), we consider the following 16 characteristics of deposit insurance design: Explicit, which equals 1 if the country has settled and implemented explicit deposit insurance system, and 0 otherwise; Coverage ratio, the coverage divided by GDP per capita ${ }^{1}$, for countries without deposit insurance system, implicit guarantee of coverage is considered as full, and value is 5,359.82\% (Angkinand and Wihlborg, 2010); Unlimited Government guarantees, which equals 1 if there is unlimited

1 The coverage and GDP per capita are in constant 2005 U.S. dollar. The variable is taken the natural logarithm in this paper and expressed as Log of GDP per capita. 
government guarantee in a country, and 0 if there is not; Foreign currency, which equals 1 if the foreign deposits are covered by the scheme, and 0 if they are not included; Interbank Deposits, it equals 1 if interbank deposits are subject to the system, and 0 if they are not; No coinsurance, it equals 1 if the scheme has no coinsurance, and 0 if it has coinsurance; Payouts, it is coded 2 if the coverage is per account, 1 if per depositor account for each institution, and 0 if per depositor; Premiums, it takes 1 if the premiums are flat, and 0 if it is risk-adjusted; Ex-ante Fund, it equals 1 if insurance funding before the crisis, and 0 if funding after the crisis; Funded by government, it equals 1 if deposit insurance is financed by the government, and 0 under other circumstance; Backstop from government, it equals 1 if deposit insurance is led and supported by government, takes 0 otherwise; Uninsured deposits, it equals 1 if no losses imposed on uninsured deposits, and 0 under other cases; Bank deposits, it equals 1 if government guarantees on bank deposits, and 0 in other cases; Non-deposit liabilities, it equals 1 if government guarantees on non-deposit liabilities, and 0 under other cases; Bank assets, it equals 1 if government guarantees on bank assets, and 0 under other situation. Administration, it equals 3 if the scheme managements are both public and private sectors, and equals 2 if the system is governed privately, and equals 1 if the scheme is administered publicly; Membership, it equals 1 if the membership is voluntary, and 0 if it is compulsory. The data is from the Deposit Insurance Database (Demirgüç-Kunt et al., 2014).

Table 1 provides descriptive statistics of all the variables used in this study, and the data is a duration type including 189 countries over 1960-2015. Table 2 only lists the correlation coefficient of Coverage ratio with other variables.

\section{Model Specification}

Note that the deposit insurance scheme is determined by multiple factors (Demirgüç-Kunt et al., 2008). Therefore, the observed values of the dependent variable (Coverage ratio) are not from the random selection samples, which may lead to biased coefficient estimates by using ordinary least squares. If ignoring differences in the two decisions about whether adopting deposit insurance system and the coverage setting, it also may lead to estimation errors. Therefore, we use Heckman two-step model to solve the problem (Heckman, 1979).

In the first stage, we use a binary Probit model to investigate whether countries adopt deposit insurance systems with all observations, and the decision can be represented by the following equations (1)-(4):

$$
y_{i}=\boldsymbol{x}_{i}^{\prime} \boldsymbol{\beta}+\varepsilon_{i}(i=1,2, \ldots, n),
$$

where the explanatory variable $y_{i}$ whether can be observed depends on the binary selection variable $z_{i}$ :

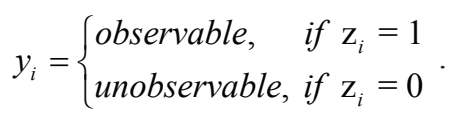

Moreover, the equation for determining the binary variable $z_{i}$ is: 


$$
\begin{gathered}
z_{i}= \begin{cases}1, & \text { if } z_{i}^{*}>0 \\
0, & \text { if } z_{i}^{*} \leq 0\end{cases} \\
z_{i}^{*}=\boldsymbol{w}_{i}^{\prime} \gamma+u_{i}
\end{gathered}
$$

where $z_{i}^{*}$ is unobservable. Assume that $u_{i}$ is subject to a normal distribution, so $z_{i}$ forms a Probit model, the formulas (1)-(4) show that whether adopt the deposit insurance scheme is determined by relevant observed variable $\boldsymbol{x}_{i}$ and the unobservable variable $z_{i}{ }^{*}$. If the deposit insurance system is established, then $y_{i}=1$, otherwise, $y_{i}=0$. While $\boldsymbol{x}_{i}$ denote characteristic variables for the individual $i$, including macroeconomic situation, political and legal system, the banks' structure and business, bank supervision, population and external pressure, etc., and $\varepsilon_{i}$ is the error term. We can get estimatior $\hat{\boldsymbol{\beta}}$ according to formulas (1)-(4), then calculate the inverse Mills ratio (Heckman's Lambda) for each individual $i$ :

$$
\lambda_{i}=\frac{\phi\left(\boldsymbol{x}_{i} \hat{\boldsymbol{\beta}}\right)}{\varphi\left(\boldsymbol{x}_{i} \hat{\boldsymbol{\beta}}\right)} .
$$

In equation (5), $\phi\left(\boldsymbol{x}_{i} \hat{\boldsymbol{\beta}}\right)$ and $\varphi\left(\boldsymbol{x}_{i} \hat{\boldsymbol{\beta}}\right)$ are standard normal distribution density function and the cumulative density function of variable $\boldsymbol{x}_{i} \hat{\boldsymbol{\beta}}$, respectively. Considering the selected samples in the second stage, that is, using observation of which the values of $y_{i}$ is 1 , do the following regression:

$$
\operatorname{Ln} Y_{i}=\boldsymbol{X}_{i}^{\prime} \boldsymbol{\delta}+\lambda_{i}+\mu_{i}
$$

In equation (6), $\operatorname{Ln} Y_{i}$ is dependent variable in the second stage, namely the natural logarithm of deposit insurance coverage in the sample years. The explanatory variable $\boldsymbol{X}_{i}$ in the second stage are similar to $\boldsymbol{x}_{i}$ but excluding external pressure variable Contagion $^{2}$, and $\mu_{i}$ is the error term. Heckman two-step requires $\boldsymbol{x}_{i}$ is a strict subset of $\boldsymbol{X}_{i}$, and $\lambda_{i}$ is inverse Mills ratio (Heckman's Lambda) obtained in the first stage. We make regression analysis between $y_{i}$ and $\boldsymbol{x}_{i}$ using Probit model with all samples to get estimated value $\boldsymbol{\beta}$, then we can estimate $\boldsymbol{\delta}$.

\section{Empirical Analysis}

We consider two types of tests to ensure the accuracy and robustness of using the Heckman two-step model. First, we use the Likelihood Ratio Test to check for the "sample selection bias" (Greene, 1981; Merton, 1977). The Likelihood Ratio Test at the bottom of Table 3 shows that the original hypothesis " $H_{0}: \rho=0$ " can be rejected. Therefore, the sample selection model should be used. Second, as the applicability of the Heckman two-step method requires no serious collinearity, the collinearity of the model can be tested by the Conditional Index (Belsley, 1991). Table 4 shows that there is no serious multicollinearity problem.

2 Contagion has little impact on determining the deposit insurance coverage setting. 
Table 3 | LR Test for Sample Selection Bias

\begin{tabular}{|l|c|c|c|c|c|c|}
\hline & Coef. & Std.Err. & $z$ & $P>z$ & \multicolumn{2}{|c|}{ [95\% Conf. Interval] } \\
\hline /athrho & 1.18 & 0.08 & 14.83 & 0.00 & 1.03 & 1.34 \\
\hline /Insigma & 0.03 & 0.02 & 1.29 & 0.20 & -0.02 & 0.07 \\
\hline rho & 0.83 & 0.03 & - & - & 0.77 & 0.87 \\
\hline sigma & 1.03 & 0.02 & - & - & 0.98 & 1.08 \\
\hline Iambda & 0.85 & 0.04 & - & - & 0.77 & 0.93 \\
\hline
\end{tabular}

LR test of indep. eqns. $(r h o=0):$ chi2 $(1)=105.05$ Prob $>$ chi2 $=0.00$

Source: Authors.

Table 4 | Condition Indexes and Variance-Decomposition Proportions

\begin{tabular}{|c|l|c|c|l|c|}
\hline Cl & \multicolumn{1}{|c|}{ Variable name } & V-DP & CI & \multicolumn{1}{|c|}{ Variable name } & V-DP \\
\hline 4.94 & Bank crisis & 0.42 & 25.67 & Undercapitalized banks & 0.31 \\
\hline 5.18 & Official exchange rate & 0.38 & 27.06 & Pop65 & 0.40 \\
\hline 6.13 & GDP growth & 0.53 & 27.06 & Capital regulatory index & 0.33 \\
\hline 8.92 & Polity score & 0.36 & 33.00 & Official supervisory power & 0.53 \\
\hline 9.27 & EU candidate & 0.39 & 34.63 & Activity restrictions & 0.53 \\
\hline 11.32 & Premiums & 0.31 & 34.63 & Asian & 0.35 \\
\hline 11.32 & Non-deposit liabilities & 0.42 & 35.68 & Uninsured deposits & 0.31 \\
\hline 12.14 & Foreign currency & 0.43 & 41.92 & Uninsured deposits & 0.44 \\
\hline 12.33 & Administration & 0.31 & 51.80 & Corruption & 0.34 \\
\hline 15.22 & No coinsurance & 0.45 & 53.35 & Log of GDP per capita & 0.75 \\
\hline 15.22 & Ex-ante fund & 0.46 & 59.70 & Corruption & 0.45 \\
\hline 25.67 & Capta & 0.49 & 133.91 & Entry restrictions & 0.49 \\
\hline
\end{tabular}

Note: Variance Decomposition Proportions less than 0.3 have not been reported.

Source: Authors.

The regression results are provided in Tables 5-7. The first-stage equation is a model of choice for deposit insurance, which measures the factors' impact on the possibility of setting up explicit deposit insurance scheme. In the second stage, the model verifies the incidence of these factors on coverage, which contains a regressor named Heckman's Lambda that is a nonlinear function of the regression factors, and this variable is used to interpret sample selection bias of coverage setting in a single-equation context. Moreover, Heckman's Lambda 
is a significant and positive coefficient in most specifications, which indicates a selection bias problem in coverage setting, thus using the Heckman two-step model is more appropriate.

It is worth noting that we use the same variables in the estimation of two-step model in Column (1) (2) and Column (3) (4) in Tables 5-7, respectively. In addition, we employ deposit insurance design characteristics in Column (3) (4) in Tables 5-7. Besides, models of Column (2) (4) include year-fixed effects in both the first-stage and secondstage regression. In the regression analysis, we consider all sample countries, developing countries, developed countries, respectively. In the regression of the whole samples, we introduce the Region_dummy variable to control the heterogeneity of the geospatial ${ }^{3}$. Next, we will have an in-depth analysis on the estimations for developing and developed countries.

Following the regression results for developing countries in Table 5, in the banking sector, higher bank competition will inhibit coverage, which is consistent with the public interest theory, that is, regulators will set lower coverage to lessen the banks' moral hazard. Lower Interest rate spread will reduce the coverage, which is in accordance with the public interest theory. On the one hand, depositors' sensitivity of bank risk may gradually improve in the process of the market-oriented interest rate, and high risk may make the part of the bank deposits divert to other financial markets. Therefore, this may reduce the banks' risk activities to a degree. On the other hand, regulators may inhibit higher deposit insurance coverage setting to cut banks' risk-taking. The upper proportion of Small banks will reduce the coverage. According to the public interest theory, compared with the large banks, small banks have a greater risk, thus regulators must control coverage within a proper level to maintain economic stability and achieve the maximization of social welfare in the implementation of the deposit insurance scheme.

On the macro-economic stand, a large proportion of the elderly population in the country will promote deposit insurance coverage. Rapid economic growth of countries will set a lower coverage. The higher inflation rate is apt to reduce the coverage setting, which is coherent with the public interest theory. The higher Household savings rate contributes to a lower coverage setting. As personal saving is one of the main sources of bank funds, most often, it may be fewer in the choice of financial products whose risk equals to deposit in high saving countries. Therefore, depositors impose weak market constraints on banks on account of higher precautionary savings motive, which may make the banks and creditors have a strong demand for deposit insurance system. However, to strengthen the market discipline on banks and reduce the moral hazard, higher personal savings may control coverage within a proper level by public interest theory. Surplus countries are likely to increase deposit insurance coverage. From the policymakers' perspective, the government expects higher coverage setting by the private interest theory. The countries with a high proportion of gross insurance premiums underwritten to GDP will reduce the coverage, which is consistent with private interest theory. In the countries with a larger force of the insurance industry, the deposit insurance institutions will implement a more stringent design scheme by considering their interests, thus coverage setting will be higher.

3 We consider five Region_dummy variables (Asia, North America, South America, Europe, and Africa) to control the six regional differences (the sixth for Oceania). 
Turning to institutional factors, the countries with stricter restrictions on banks' activities and stricter requirements to set up a bank, will increase coverage. This is consistent with the private interest theory, and it suggests that the banks in these countries have a substantial political influence, and also corroborates that more stringent entry restrictions and generous deposit insurance may add the banks' franchise value to some extent (Demirgüç-Kunt et al., 2008). The countries with more strict capital regulations in the banking system will set the lower coverage, which is not in accordance with the public interest theory. The countries with high bureaucratic quality and normative legislation will increase the coverage. According to the public interests theory, higher implementation efficiency of government can provide more service and guarantees to the public, which may conduce to a higher coverage setting. The impact from the World Bank will lead to lower coverage setting. Conversely, the pressure from the European Union may prompt some developing countries that want to join the EU set a higher coverage.

After introducing deposit insurance design features, we find that underwriting foreign currency will increase the types and amount of insured deposits. Thus banks have the incentive to lobby for increasing the coverage to reduce the potential risk, which is consistent with private interest theory. The generous Payouts will increase the effective coverage, so the banks prefer higher coverage to reduce the potential risk, which is in conformity with private interest theory. Insurance fund financing before the crisis will increase coverage, which suggest that there may become serious in moral hazard problems in the banking after establishing explicit deposit insurance scheme in developing countries. The Uninsured deposits can obtain partial compensation from liquidation as the bank bankruptcy that will increase the coverage, which suggests there is interests contradiction between insured depositors and uninsured depositors. Naturally, insured depositors require a higher security level for their savings. Government guarantees on Bank deposits will increase coverage. Membership of the deposit insurance system is voluntary, which will promote the coverage setting and also reflect the potential banks' moral hazard problems accompanied by the establishment of explicit deposit insurance scheme. On the other hand, the coverage will be reduced if deposit insurance system is funded, led and supported by the government. Moreover, government guarantees on banks' non-deposit liabilities also will restrain coverage setting, which is in accordance with the public interest theory.

We can observe some robustness of the results from the regression results of developed countries in Table 6. Countries with a high proportion of Undercapitalized banks will raise the coverage. According to the private interest theory, greater risk and powerful banks will lobby regulators to improve the coverage setting in anticipation of that may subsidize the cost of their risk behaviour. During the crisis, coverage setting is higher, which contributes to protecting depositors' interests and enhancing public confidence in banks. This is consistent with the public interest theory. The countries with more stringent capital regulations in the banking system will set the higher coverage, which is in accordance with the public and private interest theory. The countries with strict bank regulation will set higher coverage, and this is consistent with public interest theory. 
Table 5 | Heckman Two-Step Selection Model Based on Deposit Insurance Coverage for Developing Countries

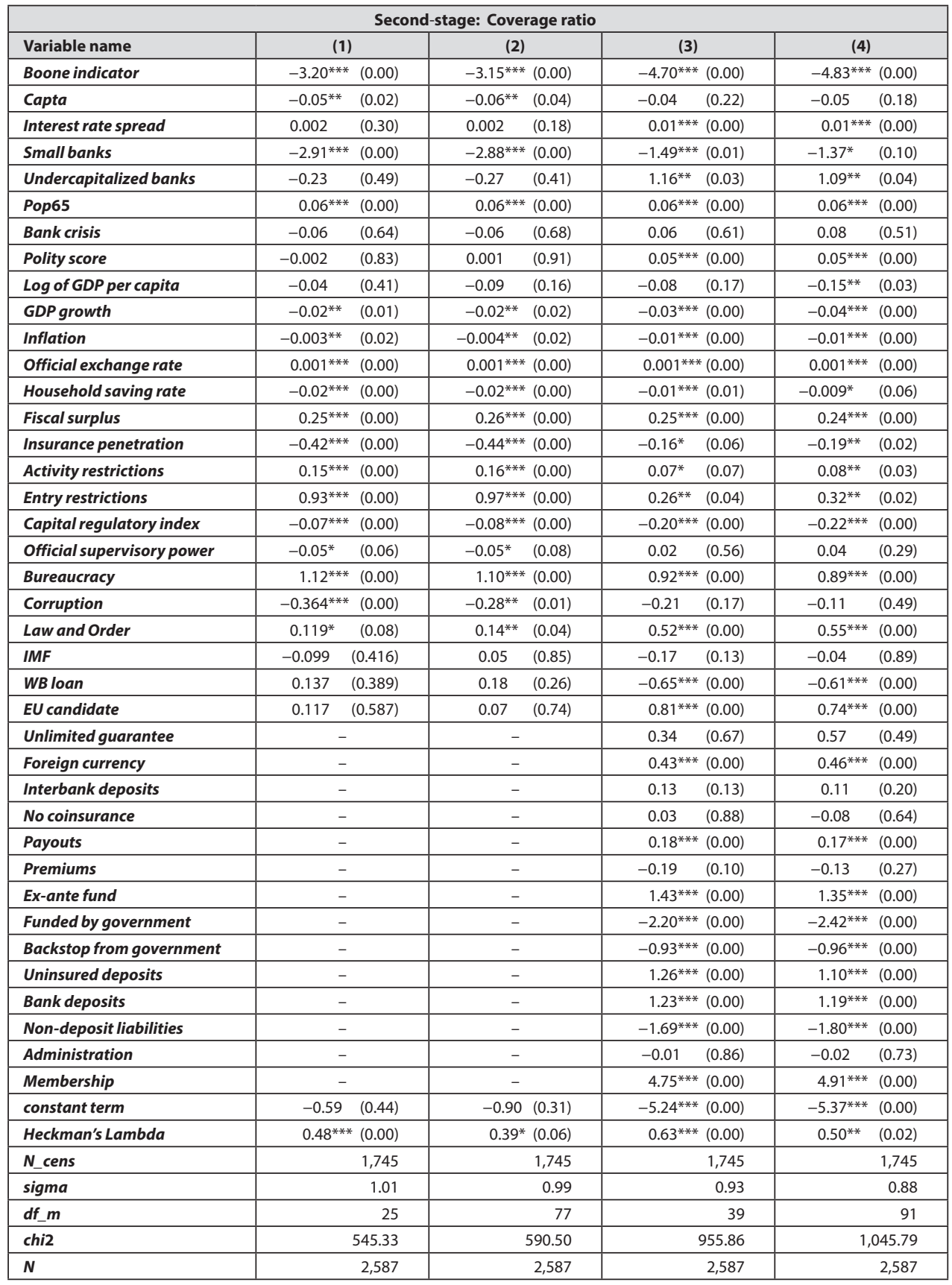

Note: Refer to Section 3. Bank assets is omitted because of collinearity by Sata MP 13.1

$*^{*},{ }^{* * * *}$ represent the $10 \%, 5 \%, 1 \%$ significance level, respectively. The numbers in parentheses are $p$-values. Source: Authors. 
A large proportion of the elderly population throughout the country will promote the coverage, and democratic countries will improve the coverage, which conform with public interest theory. The countries with good bureaucratic quality will decrease the coverage, according to the public interest theory, great policy-making abilities and implementation efficiency of government may impose more controls on banks to reduce their moral hazard. The developed countries with more normative legislation will increase the coverage, because bank interest groups may have an impact on the legislature to raise coverage according to the private interest theory. External pressure from the World Bank loan program will lead to higher coverage in developed countries.

After considering the deposit insurance design characteristics variables, underwriting Interbank deposits will increase the types and amount of insured deposits, thus regulators may reduce the coverage to restrain the banks' risk-taking incentives, which is coherent with the private interest theory. Implementation of No coinsurance will increase coverage, because co-insurance requires depositors to bear the partial loss in the event of bank failure, so it may increase depositors' supervision incentive on risk activities and decrease the coverage according to the public interest theory. However, lower coverage may make investors lose interest in deposit rates and bring about financial disintermediation. Therefore, according to private interest theory, the coverage needs to be raised. The generous Payouts will decrease coverage, because the regulators can set lower coverage to dampen the banks' moral hazard, which is consistent with public interest theory. If all banks pay the same premium, the insurance system may create subsidies that are from the lower-risk banks to the higher-risk banks. Thus regulators may inhibit coverage to control banks' risk-taking incentives by the public interest theory. Insurance fund financing before the crisis will increase coverage setting which is consistent with the private interest theory. If asked to pay the insurance premium in the wake of the crisis, banks may lobby regulator to set higher coverage to reduce the uncertainty cost to the greatest extent in the future. On the other hand, deposit insurance system led and supported by government will increase the coverage. Besides, government guarantees on banks' deposit also will increase coverage, which is in accordance with private interest. However, government guarantees on banks' non-deposit liabilities will restrain coverage setting, which is consistent with the public interest.

Table 7 provides the estimations for all counties. We find that signs and significance levels for the coefficient of Small banks, Insurance penetration, Bank crisis, Polity score, Bureaucracy, Law and Order, Inflation, Activity restrictions, and Official supervisory power are consistent with the research (Demirgüç-Kunt et al., 2008) in the most regressions.

However, the coefficient of EU candidate is positive and significant, which is entirely opposite to that of Demirgüç-Kunt et al. (2008). It may indicate that the pressure from the European Union increases deposit coverage setting as time goes by, which is consistent with the public interest theory. This finding is in accordance with the actual situation (Gros and Schoenmaker, 2014). On the other hand, according to Demirgüç-Kunt et al. (2014), during the 2008 financial crisis, the vast majority of the countries raise the effective coverage ratio to maintain the stability of the banking sector. 
Table 6 | Heckman Two-Step Selection Model Based on Deposit Insurance Coverage for Developed Countries

\begin{tabular}{|c|c|c|c|c|}
\hline \multicolumn{5}{|c|}{ Second-stage: Coverage ratio } \\
\hline Variable name & (1) & (2) & (3) & (4) \\
\hline Boone indicator & $-1.71 * * *(0.01)$ & $-2.01^{* * *}(0.00)$ & $40.66^{* * *}(0.00)$ & $23.58^{* * *}(0.00)$ \\
\hline Capta & $0.23^{* * *}(0.00)$ & $0.23^{* * *}(0.00)$ & $-2.05^{* * *}(0.00)$ & $-0.36 \quad(0.51)$ \\
\hline Interest rate spread & $-0.004 \quad(0.89)$ & $\begin{array}{ll}-0.01 & (0.79) \\
\end{array}$ & $1.81^{* * *}(0.00)$ & $1.42^{* * *}(0.00)$ \\
\hline Small banks & $-13.26^{* * *}(0.00)$ & $-14.2^{* * *}(0.00)$ & $64.23 * *(0.03)$ & $-16.03 \quad(0.57)$ \\
\hline Undercapitalized banks & $1.62^{* * *}(0.00)$ & $1.42^{* * *}(0.00)$ & $5.71^{* * *}(0.00)$ & $4.76^{* * *}(0.00)$ \\
\hline Pop65 & $0.08^{* * *}(0.00)$ & $0.08^{* * *}(0.00)$ & $0.10^{* * *}(0.00)$ & $0.06^{* *}(0.03)$ \\
\hline Bank crisis & $0.63^{* * *}(0.00)$ & $0.21 * *(0.05)$ & $0.56^{* * *}(0.00)$ & $0.48^{* * *}(0.00)$ \\
\hline Polity score & $0.25^{* * *}(0.00)$ & $0.26^{* * *}(0.00)$ & $0.39 * * *(0.00)$ & $0.39 * * *(0.00)$ \\
\hline Log of GDP per capita & $-0.12 \quad(0.13)$ & $-0.42 * *(0.02)$ & $-0.09 \quad(0.28)$ & $0.91^{* * *}(0.00)$ \\
\hline GDP growth & $-0.02 * *(0.04)$ & $-0.01 \quad(0.50)$ & $-0.02^{*}(0.09)$ & $-0.01 \quad(0.62)$ \\
\hline Inflation & $0.04^{* * *}(0.00)$ & $0.03 * *(0.03)$ & $0.03^{* * *}(0.00)$ & $0.01 \quad(0.43)$ \\
\hline Official exchange rate & $0.001 * *(0.03)$ & $0.001^{* * *}(0.01)$ & $0.002 \quad(0.24)$ & $0.01^{* * *}(0.00)$ \\
\hline Household saving rate & $-0.02^{* * *}(0.00)$ & $-0.01^{* * *}(0.00)$ & $0.20^{* * *}(0.00)$ & $0.16^{* * *}(0.00)$ \\
\hline Fiscal surplus & $0.11^{* * *}(0.00)$ & $0.11^{* * *}(0.00)$ & $-1.42^{* * *}(0.00)$ & $-1.03^{* * *}(0.00)$ \\
\hline Insurance penetration & $-0.02 \quad(0.54)$ & $-0.01 \quad(0.77)$ & $1.35^{* * *}(0.00)$ & $0.57^{* *}(0.03)$ \\
\hline Activity restrictions & $0.14 * * *(0.00)$ & $0.130 * * *(0.00)$ & $0.89 * *(0.03)$ & $-0.30 \quad(0.44)$ \\
\hline Entry restrictions & $-0.39 * * *(0.00)$ & $-0.46^{* * *}(0.00)$ & $4.27^{* * *}(0.00)$ & $3.12^{* * *}(0.00)$ \\
\hline Capital regulatory index & $0.19^{* * *}(0.00)$ & $0.10^{* *}(0.02)$ & $3.69 * * * *(0.00)$ & $2.13^{* * *}(0.00)$ \\
\hline Official supervisory power & $-0.10^{* * *}(0.00)$ & $-0.09 * * *(0.00)$ & $-0.81^{* * *}(0.00)$ & $-0.33^{* *}(0.03)$ \\
\hline Bureaucracy & $-0.77^{* * *}(0.00)$ & $-0.73^{* * *}(0.00)$ & $-1.32^{*} \quad(0.07)$ & $-2.50^{* * *}(0.00)$ \\
\hline Corruption & $0.26^{* *}(0.02)$ & $0.32^{* * *}(0.00)$ & $-0.002 \quad(0.99)$ & $1.25^{* * *}(0.01)$ \\
\hline Law and Order & $0.74^{* * *}(0.00)$ & $0.59 * * *(0.00)$ & $9.00 * * * * 0.00)$ & $7.43^{* * *}(0.00)$ \\
\hline IMF & $-0.25^{* * *}(0.01)$ & $1.05 \quad(0.27)$ & $-0.49 * * *(0.00)$ & $-2.87^{* * *}(0.00)$ \\
\hline WB loan & $1.30^{* * *}(0.00)$ & $0.72 * *(0.04)$ & $18.49^{* * *}(0.00)$ & $10.89 * * *(0.00)$ \\
\hline EU candidate & $1.69^{* * *}(0.00)$ & $1.43^{* * *}(0.00)$ & $-6.09^{* * *}(0.00)$ & $-0.65 \quad(0.74)$ \\
\hline Foreign currency & - & - & $\begin{array}{ll}0.02 & (0.95) \\
\end{array}$ & $0.29 \quad(0.35)$ \\
\hline Interbank deposits & - & - & $-3.18^{* * *}(0.00)$ & $-2.88^{* * *}(0.00)$ \\
\hline No coinsurance & - & - & $1.20^{* * *}(0.00)$ & $0.36^{* * *}(0.00)$ \\
\hline Payouts & - & - & $-0.27^{* * *}(0.00)$ & $-0.74 * * *(0.00)$ \\
\hline Premiums & - & - & $-1.85 * * *(0.00)$ & $-1.26^{* * *}(0.00)$ \\
\hline Ex-ante fund & - & - & $1.32 * \quad(0.09)$ & $4.32 * * *(0.00)$ \\
\hline Funded by government & - & - & $-9.62^{* * *}(0.00)$ & $0.37 \quad(0.91)$ \\
\hline Backstop from government & - & - & $4.74 * * *(0.00)$ & $3.73^{* * *}(0.00)$ \\
\hline Bank deposits & - & - & $9.60 * * *(0.00)$ & $4.98^{* * *}(0.00)$ \\
\hline Non-deposit liabilities & - & - & $-15.01 * * *(0.00)$ & $-10.48^{* * *}(0.00)$ \\
\hline Bank assets & - & - & $-3.61 * * *(0.00)$ & $0.10 \quad(0.94)$ \\
\hline Administration & - & - & $-0.12 \quad(0.18)$ & $-0.10 \quad(0.21)$ \\
\hline Membership & - & - & $1.87 \quad(0.12)$ & $0.67 \quad(0.55)$ \\
\hline constant term & $0.46(0.77)$ & $4.32 * *(0.01)$ & $-99.76^{* * *}(0.00)$ & $-85.86^{* * *}(0.00)$ \\
\hline Heckman's Lambda & $0.32 *(0.06)$ & $-0.23(0.12)$ & $0.36^{* * *}(0.01)$ & $0.24^{* *}(0.04)$ \\
\hline N_cens & 486 & 486 & 486 & 486 \\
\hline sigma & 0.83 & 0.74 & 0.63 & 0.54 \\
\hline$d f \_m$ & 25 & 78 & 38 & 91 \\
\hline chi2 & $1,009.76$ & $1,435.92$ & $2,430.16$ & $3,332.98$ \\
\hline$N$ & 1,216 & 1,216 & 1,216 & 1,216 \\
\hline
\end{tabular}

Note: Refer to Section 3. Unlimited guarantee is omitted because of collinearity by Sata MP 13.1

$* *^{* *}, * * *$ represent the $10 \%, 5 \%, 1 \%$ significance level, respectively. The numbers in parentheses are $p$-values.

Source: Authors. 
Table 7 | Heckman Two-Step Selection Model Based on Deposit Insurance Coverage for All Countries

\begin{tabular}{|c|c|c|c|c|}
\hline \multicolumn{5}{|c|}{ Second-stage: Coverage ratio } \\
\hline Variable name & (1) & (2) & (3) & (4) \\
\hline Boone indicator & $0.14 \quad(0.71)$ & $0.04 \quad(0.92)$ & $0.52 \quad(0.17)$ & $0.29 \quad(0.45)$ \\
\hline Capta & $0.08^{* * *}(0.00)$ & $0.08^{* * *}(0.00)$ & $0.13^{* * *}(0.00)$ & $0.16^{* * *}(0.00)$ \\
\hline Interest rate spread & $0.01^{* * *}(0.00)$ & $0.01^{* * *}(0.00)$ & $0.01^{* * *}(0.00)$ & $0.01 * * *(0.00)$ \\
\hline Small banks & $-3.17^{* * *}(0.00)$ & $-3.58^{* * *}(0.00)$ & $-3.57^{* * *}(0.00)$ & $-4.77^{* * *}(0.00)$ \\
\hline Undercapitalized banks & $1.35^{* * *}(0.00)$ & $1.33^{* * *}(0.00)$ & $1.39 * * *(0.00)$ & $1.28^{* * *}(0.00)$ \\
\hline Pop65 & $-0.01 \quad(0.30)$ & $-0.02 \quad(0.18)$ & $0.03 * \quad(0.06)$ & $0.04 * *(0.02)$ \\
\hline Bank crisis & $0.49^{* * *}(0.00)$ & $0.42^{* * *}(0.00)$ & $0.40^{* * *}(0.00)$ & $0.30^{* * *}(0.00)$ \\
\hline Polity score & $0.04^{* * *}(0.00)$ & $0.04^{* * *}(0.00)$ & $0.03 * * *(0.01)$ & $0.03^{* * *}(0.00)$ \\
\hline Log of GDP per capita & $0.14^{* * *}(0.00)$ & $0.04 \quad(0.52)$ & $-0.07 \quad(0.14)$ & $-0.28^{* * *}(0.00)$ \\
\hline GDP growth & $-0.03^{* * *}(0.00)$ & $-0.04 * * *(0.00)$ & $-0.02^{* * *}(0.00)$ & $-0.03^{* * *}(0.00)$ \\
\hline Inflation & $-0.01 * * *(0.00)$ & $-0.01 * * *(0.00)$ & $-0.01 * * *(0.00)$ & $-0.01^{* * *}(0.00)$ \\
\hline Official exchange rate & $0.00^{* * * *}(0.00)$ & $0.00^{* * *}(0.00)$ & $0.001 * * *(0.00)$ & $0.001^{* * *}(0.00)$ \\
\hline Household saving rate & $-0.03^{* * *}(0.00)$ & $-0.02^{* * *}(0.00)$ & $-0.02^{* * *}(0.00)$ & $-0.02^{* * *}(0.00)$ \\
\hline Fiscal surplus & $0.11^{* * *}(0.00)$ & $0.11^{* * *}(0.00)$ & $0.11 * * *(0.00)$ & $0.11^{* * *}(0.00)$ \\
\hline Insurance penetration & $-0.16^{* * *}(0.00)$ & $-0.16^{* * *}(0.00)$ & $0.02 \quad(0.44)$ & $\begin{array}{ll}0.02 & (0.39) \\
\end{array}$ \\
\hline Activity restrictions & $0.09^{* * *}(0.00)$ & $0.09^{* * *}(0.00)$ & $0.10^{* * * *}(0.00)$ & $0.08^{* * *}(0.01)$ \\
\hline Entry restrictions & $-0.02 \quad(0.76)$ & $-0.02 \quad(0.66)$ & $-0.37^{* * *}(0.00)$ & $-0.39^{* * *}(0.00)$ \\
\hline Capital regulatory index & $0.06^{* *}(0.02)$ & $0.05^{* *}(0.02)$ & $-0.07 * * *(0.00)$ & $-0.06^{* *}(0.01)$ \\
\hline Official supervisory power & $-0.05^{* * *}(0.01)$ & $-0.05^{* * * *}(0.01)$ & $0.07^{* * *}(0.00)$ & $0.07^{* * *}(0.00)$ \\
\hline Bureaucracy & $\begin{array}{ll}0.16^{*} & (0.07) \\
\end{array}$ & $0.16^{*} \quad(0.06)$ & $\begin{array}{ll}0.05 & (0.62) \\
\end{array}$ & $0.02(0.79)$ \\
\hline Corruption & $-0.10 \quad(0.24)$ & $-0.07 \quad(0.41)$ & $-0.16^{* *} \quad(0.05)$ & $-0.12(0.13)$ \\
\hline Law and Order & $-0.265^{* * *}(0.00)$ & $-0.24^{* * *}(0.00)$ & $0.17^{* *}(0.01)$ & $0.28^{* * *}(0.00)$ \\
\hline IMF & $-0.01 \quad(0.91)$ & $\begin{array}{ll}0.27 \quad(0.81) \\
\end{array}$ & $\begin{array}{ll}-0.07 \quad(0.41) \\
\end{array}$ & $0.83(0.41)$ \\
\hline WB loan & $\begin{array}{ll}0.03 & (0.83) \\
\end{array}$ & $\begin{array}{ll}0.03 & (0.85) \\
\end{array}$ & $(0.51)$ & $0.03 \quad(0.82)$ \\
\hline EU candidate & $0.36^{* * *}(0.00)$ & $0.38^{* * *}(0.00)$ & $0.15 \quad(0.21)$ & $0.15(0.23)$ \\
\hline Region_dummy & Control & Control & Control & Control \\
\hline Unlimited guarantee & - & - & $-2.39 * * *(0.00)$ & $-2.56^{* * *}(0.00)$ \\
\hline Foreign currency & - & - & $0.63^{* * *}(0.00)$ & $0.65^{* * *}(0.00)$ \\
\hline Interbank deposits & - & - & $-0.05 \quad(0.54)$ & $-0.13^{*} \quad(0.09)$ \\
\hline No coinsurance & - & - & $0.56^{* * *}(0.00)$ & $0.35^{* * *}(0.00)$ \\
\hline Payouts & - & - & $0.10 * *(0.02)$ & $0.02 \quad(0.67)$ \\
\hline Premiums & - & - & $0.08 \quad(0.30)$ & $\begin{array}{ll}0.08 & (0.30) \\
\end{array}$ \\
\hline Ex-ante fund & - & - & $0.32^{* * *}(0.00)$ & $0.27^{* * *}(0.01)$ \\
\hline Funded by government & - & - & $-3.00 * * *(0.00)$ & $-3.45^{* * *}(0.00)$ \\
\hline Backstop from government & - & - & $-0.34^{* * *}(0.00)$ & $-0.39^{* * *}(0.00)$ \\
\hline Uninsured deposits & - & - & $0.53^{*} \quad(0.07)$ & $0.64^{* *}(0.03)$ \\
\hline Bank deposits & - & - & $-0.65^{* * *}(0.00)$ & $-0.60^{* * *}(0.00)$ \\
\hline Non-deposit liabilities & - & - & $-0.51 * * *(0.00)$ & $-0.48^{* * *}(0.00)$ \\
\hline Bank assets & - & - & $-0.27 * *(0.04)$ & $-0.29 * *(0.03)$ \\
\hline Administration & - & - & $0.09 * * \quad(0.02)$ & $0.12^{* * *}(0.00)$ \\
\hline Membership & - & - & $1.70^{* * *}(0.00)$ & $1.52^{* * *}(0.00)$ \\
\hline constant term & $4.47^{* * *}(0.00)$ & $4.99^{* * *}(0.00)$ & $7.54 * * *(0.00)$ & $8.75^{* * *}(0.00)$ \\
\hline Heckman's Lambda & $0.76^{* * *}(0.00)$ & $0.73^{* * *}(0.00)$ & $0.55^{* * *}(0.00)$ & $0.68^{* * *}(0.00)$ \\
\hline N_cens & 2,231 & 2,231 & 2,231 & 2,231 \\
\hline sigma & 1.12 & 1.09 & 0.96 & 0.97 \\
\hline$d f \_m$ & 30 & 83 & 45 & 98 \\
\hline chi2 & 795.90 & 890.44 & $1,501.57$ & $1,568.76$ \\
\hline$N$ & 3,803 & 3,803 & 3,803 & 3,803 \\
\hline
\end{tabular}

Note: Refer to Section $3 .{ }^{*}, * * * * *$ represent the $10 \%, 5 \%, 1 \%$ significance level, respectively.

The numbers in parentheses are $f$-values.

Source: Authors. 


\section{Conclusion}

This paper employs the Heckman two-step model and duration data of 189 countries from 1960 to 2015, and finds that the macroeconomic situation, banks' structure and business, banking supervision, political and legal system, population, external pressures, deposits insurance design characteristics have a significant impact on the coverage of developing countries and developed countries, respectively.

Through the empirical analyses of the different samples, we obtain the following robust results: higher proportion of Undercapitalized banks and strict requirements on banks' activities will increase deposit insurance coverage; coverage will be higher during Bank crisis; higher old population proportion and devaluation degree of domestic currency also will improve coverage; higher degree of political democracy will enhance coverage; the countries with the faster economic growth will set a lower coverage. On the other hand, design characteristics of the deposit insurance scheme also have an impact on coverage setting. We explore that funding before the crisis would increase coverage. However, when the government guarantees on banks' non-deposit liabilities, it will make set the lower coverage.

Furthermore, this paper suggests that the impact factors in developing and developed countries reflect some differences. For developing countries, higher Household saving rate, Insurance penetration and Capital regulatory index will increase the coverage. Moreover, the pressure from the European Union will make candidate countries improve the coverage level. The scheme covers the Foreign currency will support a higher coverage. Turning to the developed countries, strong Official supervisory power for banks and good bureaucracy quality will decrease the coverage, the pressure from the World Bank loan program has the positive effect on coverage. The deposit insurance covers the Interbank deposits will lead to a lower coverage, and the scheme has No coinsurance will hold up a higher coverage.

It is noteworthy that Payouts and Backstop from government both influence the coverage setting in the opposite direction in different samples. The generous Payouts leave the coverage increased, which indicates that banking sector has a stronger position and higher moral hazard in developing countries after establishing the deposit insurance system. Due to the choice of Payouts involves the calculation of "real effective coverage" (Demirgüç-Kunt et al., 2014). Therefore, the research on the specific underwriting of coverage (Payouts) has important significance to design a more reasonable and effective deposit insurance system in the future.

\section{References}

Acharya, S. (1996). Charter Value, Minimum Bank Capital Requirement and Deposit Insurance Pricing in Equilibrium. Journal of Banking \& Finance, 20(2), 351-375, http://doi.org/10.1016/0378-4266(94)00126-X

Aiyagari, S. R. (1994). Uninsured Idiosyncratic Risk and Aggregate Saving. The Quarterly Journal of Economics, 109(3), 659-684, http://doi.org/10.2307/2118417 
Angkinand, A., Wihlborg, C. (2010). Deposit Insurance Coverage, Ownership, and Banks' RiskTaking in Emerging Markets. Journal of International Money and Finance, 29(2), 252-274, http://doi.org/10.1016/j.jimonfin.2009.08.001

Barth, J. R., Caprio Jr, G., Levine, R. (2004). Bank Regulation and Supervision: What Works Best? Journal of Financial Intermediation, 13(2), 205-248, http://doi.org/10.1016/j.jfi.2003.06.002

Barth, J. R., Jr, G. C., Levine, R. (2013). Bank Regulation and Supervision in 180 Countries from 1999 to 2011. Journal of Financial Economic Policy, 5(2), 111-219, http://doi. org/10.1108/17576381311329661

Becker, G. (1976). Toward a More General Theory of Regulation. The Journal of Law \& Economics, 19(2), 245-248, http://doi.org/10.1086/466867

Becker, G. S. (1983). A Theory of Competition among Pressure Groups for Political Influence. The Quarterly Journal of Economics, 98(3), 371-400, http://doi.org/10.2307/1886017

Belsley, D. A. (1991). A Guide to Using the Collinearity Diagnostics. Computational Economics, 4(1), 33-50, http://doi.org/10.1007/BF00426854

Boyd, J. H., De NicolÓ, G. (2005). The Theory of Bank Risk Taking and Competition Revisited. The Journal of Finance, 60(3), 1329-1343, http://doi.org/10.1111/j.1540-6261.2005.00763.x

Demirgüç-Kunt, A., Kane, E. J., Laeven, L. (2008). Determinants of Deposit-Insurance Adoption and Design. Journal of Financial Intermediation, 17(3), 407-438, http://doi.org/10.1016/j. jfi.2007.03.009

Demirgüç-Kunt, A., Kane, E. J., Laeven, L. (2014). Deposit Insurance Database. The World Bank. Policy Research Working Papers No. 6934.

Diamond, D. W., Dybvig, P. H. (1983). Bank Runs, Deposit Insurance, and Liquidity. Journal of Political Economy, 91(3), 401-419, https://doi.org/10.1086/261155

Garcia, G. G. H. (2000). Deposit Insurance: Actual and Good Practices. Washington: International Monetary Fund. ISBN 9781557759481.

Greene, W. H. (1981). Sample Selection Bias as a Specification Error: A Comment. Econometrica, 49(3), 795-798, http://doi.org/10.2307/1911523

Gros, D., Schoenmaker, D. (2014). European Deposit Insurance and Resolution in the Banking Union. JCMS: Journal of Common Market Studies, 52(3), 529-546, http://doi.org/10.1111/ jcms.12124

Heckman, J. J. (1976). The Common Structure of Statistical Models of Truncation, Sample Selection and Limited Dependent Variables and a Simple Estimator for Such Models. Annals of Economic and Social Measurement. 5. Cambridge: National Bureau of Economic Research. ISSN 0044-832X.

Heckman, J. J. (1979). Sample Selection Bias as a Specification Error. Econometrica, 47(1), 153-161, http://doi.org/10.2307/1912352

IADI (2009). Governance of Deposit Insurance Systems, Guidance Paper, Prepared by Research and Guidance Committee. Basel: International Association of Deposit Insurers.

Jayaratne, J., Strahan, P. E. (1996). The Finance-Growth Nexus: Evidence from Bank Branch Deregulation. The Quarterly Journal of Economics, 111(3), 639-670, http://doi. org/10.2307/2946668

Kroszner, R. S., Stratmann, T. (1998). Interest-Group Competition and the Organization of Congress: Theory and Evidence from Financial Services' Political Action Committees. The American Economic Review, 88(5), 1163-1187.

Laeven, L. (2004). The Political Economy of Deposit Insurance. Journal of Financial Services Research, 26(3), 201-224, http://doi.org/10.1023/B:FINA.0000040049.53563.e1 
Merton, R. C. (1977). An Analytic Derivation of the Cost of Deposit Insurance and Loan Guarantees: An Application of Modern Option Pricing Theory. Journal of Banking \& Finance, 1(1), 3-11, http://doi.org/10.1016/0378-4266(77)90015-2

Saunders, A., Schumacher, L. (2000). The Determinants of Bank Interest Rate Margins: an International Study. Journal of International Money and Finance, 19(6), 813-832, http://doi.org/10.1016/S0261-5606(00)00033-4

Shy, O., Stenbacka, R., Yankov, V. (2016). Limited Deposit Insurance Coverage and Bank Competition. Journal of Banking \& Finance, 71(1), 95-108, http://doi.org/10.1016/j. jbankfin.2016.05.002

Stigler, G. J. (1971). The Theory of Economic Regulation. The Bell Journal of Economics and Management Science, 2(1), 3-21, http://doi.org/10.2307/3003160

World Bank (2004). Deposit Insurance-Reforms Supported by the World Bank During the Period 1993-2004. Mimeo. Washington, DC: Operations Evaluation Department of World Bank. 